\title{
Edukasi Pencegahan Diare melalui Perilaku Hand Wash pada Anak Sekolah Dasar SD 9/IV Kota Jambi
}

\author{
Armina $^{1}$, Ratu Kusuma ${ }^{2}$. \\ ${ }^{1}$ Program Studi S1 Keperawatan, STIKes Baiturrahim Jambi \\ 2 Program Studi Profesi Ners, STIKes Baiturrahim Jambi \\ Email: arminanurwa86@gmail.com
}

Submitted : 22/12/2020

Accepted: 09/11/2021

Published: 18/11/2021

\begin{abstract}
The incidence of diarrhea is often experienced by children. Based on Riskesdas data, during 2018 there were $12.3 \%$ cases of diarrhea in Indonesia. Jambi province cases of incidence in children are about $8.6 \%$ based on health profile data in 2017 the coverage of handling diarrhea in children reaches $43.79 \%$ which exceeds the target for handling diarrhea, which is $10 \%$. Diarrhea in schoolage children can be caused by an unsanitary environment, snacking habits at school and rarely washing hands. Based on observations at SD 9/IV Jambi City, there were food vendors in front of the school, beside the SD there were trash bins and were large enough that they looked unclean where this could create a bad smell for the elementary school children and there were many food vendors in front of the school. Elementary school makes children often buy these foods. Therefore, the service team is interested in conducting counseling with the title of diarrhea prevention with hand washing behavior at SD 9/IV Jambi City. The service was carried out in June 2020. The service was carried out in the form of counseling. Based on the results of the service, children of primary school age experienced an increase in knowledge about diarrhea prevention and experienced an increase in hand washing. The results of this service are expected that the children of SD 9/IV Jambi City are able to prepare to wash their hands before eating or snacking while at school and even at home.
\end{abstract}

Keywords: diarrhea, hand wash, school children

\begin{abstract}
Abstrak
Kejadian diare sering dialami oleh anak-anak. Berdasarkan data Riskesdas bahwa selama pada tahun 2018 ditemukan kasus diare di Indonesia ditemukan sekitar 12,3\%. provinsi Jambi kasus kejadian Diare pada anak yaitu sekitar 8,6\% sedangkan berdasarkan data profil kesehatan tahun 2017 cakupan penanganan diare pada anak mencapai 43,79\% yang melebihi target nasional penanganan diare yaitu $10 \%$. Diare pada anak-anak usia sekolah dapat disebabkan karena lingkungan kurang bersih, kebiasaan Jajan di sekolah dan jarang cuci tangan. Berdasarkan hasil pengamatan awal di SD 9/IV Kota Jambi, tampak penjaja makanan di depan sekolah, di samping SD terdapat tempat sampah dan got cukup besar sehingga tampak kurang bersih dimana hal ini dapat membuat aroma kurang sedap untuk anak SD tersebut dan banyaknya penjaja makanan di depan SD membuat anak sering membeli makanan tersebut. Oleh karena itu, tim pengabdian tertarik melakukan penyuluhan dengan judul pencegahan diare dengan perilaku Hand Wash di SD 9/IV Kota Jambi. Pengabdian dilakukan pada bulan Juni 2020. Pengabdian dilakukan dalam bentuk penyuluhan. Berdasarkan hasil pengabdian anak-anak usia sekolah dasar mengalami peningkatan pengetahuan mengenai pencegahan diare dan mengalami peningkatan hand wash. Hasil pengabdian ini diharapakan anak-anak SD 9/IV Kota Jambi mampu membiasakan cuci tangan (hand wash) sebelum makan atau jajan selama di sekolah bahkan di rumah.
\end{abstract}

Kata Kunci: anak sekolah, cuci tangan, diare

\section{PENDAHULUAN}

Derajat kesehatan menjadi indikator ukuran kesehatan suatu bangsa selain itu juga anak merupakan generasi penerus suatu bangsa sehingga kesehatan anak-anak harus menjadi menjadi perhatian yang 
utama. Salah satu kasus infeksi yang sering dialami pada anak-anak hingga usia sekolah adalah kasus diare pada anak. Berdasarkan hasil temuan Riset Kesehatan dasar 2018 bahwa kesehatan anak selalu termasuk dalam kategori penilaian terutama penilaian penemuan angka kasus kesakitan. Kasus angka kesakitan yang masih menjadi penemuan adalah kasus penyakit infeksi yang cenderung sering dialami oleh anakanak. Angka kesakitan terhadap penyakit infeksi salah satunya penyakit diare. Berdasarkan data Riskesdas bahwa selama pada tahun 2018 ditemukan kasus diare di Indonesia ditemukan sekitar $12,3 \%$. Kasus Diare ini terjadi penurunan dari tahun sebelumnya menurut Kemenkes RI 2018 yaitu 18,5\% (Riskesdas, 2018). Hal ini menunjukkan kasus diare di Indonesia telah mengalami penurunan namun masih berada diatas angka belasan persen yang artinya menunjukkan angka yang masih tinggi

Berdasarkan data Riskesdas 2018 ditemukan bahwa di provinsi Jambi kasus kejadian Diare pada anak yaitu sekitar 8,6\% sedangkan berdasarkan data profil kesehatan tahun 2017 cakupan penanganan diare pada anak mencapai $43,79 \%$ yang melebihi target nasional penanganan diare yaitu $10 \%$. Hal ini menandakan bahwa kasus diare pada tahun 2018 di Provinsi Jambi terjadi penurunan dibanding tahun 2017 begitu juga dengan kasus diare di Kota Jambi. Kasus diare pada anak di kota Jambi terjadi peningkatan selama tahun 2017 hingga 2018 berdasarkan data Dinas Kesehatan Kota Jambi yaitu tercatat terjadi peningkatan diare dari 3042 (tahun 2017) menjadi 3765 (tahun 2018). Kasus diare pada anak di Kota Jambi selama tahun 2018 banyak terjadi di Wilayah Kerja Puskesmas Putri Ayu yang merupakan kasus terbanyak kedua dengan peningkatan dari 361 anak diare (tahun 2017) menjadi 561 (tahun 2018).

Kejadian diare pada anak kecil tidak terlepas dari peran orangtua sebagai pengontrol anak. Selain itu diare pada anak usia sekolah dapat diperoleh dari pola kebiasaan hidup bersih sehat yang kurang salah satunya dengan kebiasaan Hand Wash sebelum makan dan sesudah melakukan sesuatu. Berdasarkan hasil survei awal ke SD 9/IV Kota Jambi, tim pengabmas melihat di bahwa di depan Sekolah Dasar terdapat banyak penjaja makanan dan berdekatan dengan tempat sampah dan got yang beresiko terhadap risiko makanan yang terhinggap lalat. Selain itu, anak SD juga banyak makan dari penjaja tersebut dan terlihat ada yang membersihkan tangan terlebih dahulu dan ada yang tidak sehingga berisiko anak SD mengalami diare. Sehingga tim pengabdian masyarakat tertarik melakukan pengabdian masyarakat kepada anak sekolah dasar tersebut.

\section{TARGET DAN LUARAN}

Sasaran dari mitra pengabdian ini adalah anak sekolah kelas 1 atau 2 SD 9/IV Kota Jambi. Luaran yang diharapkan dari kegiatan pengabdian yang dilaksanakan berupa peningkatan pengetahuan, penerapan IPTEK (praktik hand wash) di masyarakat yaitu anak Usia Sekolah dan publikasi di jurnal abdimas nasonal terdaftar ISSN atau terakreditasi.

\section{METODE PELAKSANAAN}

Waktu pelaksanaan pengabdian masyarakat ini dilakukan dalam rentang waktu Feburari hingga Juli 2020. Adapun tahapan pelaksanaan kegiatan mulai dari edukasi pencegahan diare secara umum kepada anak SD kemudian demonstrasi hand wash (cuci tangan). Adapaun kegiatan pengabdian ini dilaksanakan ke rumahrumah anak sekolah dasar yang bukan hanya kelas 1 atau kelas 2 saja namun pada kelas berapa saja yang berada di sekitar lingkungan sekolah dasar SD 19/IV Kota Jambi oleh karena kondisi pandemi COVID-19 yang menganjurkan untuk berada di rumah dan menjaga jarak. 


\section{HASIL DAN PEMBAHASAN}

Kegiatan penyuluhan dalam rangka upaya peningkatan kognitif anak SD berlangsung kurang lebih 30 menit dan terlaksana dengan tertib dan lancar serta mendapat mendapat sambutan yang baik oleh orangtua. Berdasarkan hasil pengabdian antusias peserta pengabdian mengalami peningkatan pengetahuan mengenai hand wash dalam pencegahan diare. Anak-anak bisa memahami penyebab diare bahwa diare bisa sebabkan oleh tangan yang kurang bersih sebelum makan, pencegahan diare salah satunya dengan mencuci tangan (hand wash), anak-anak bisa mendemonstrasikan cara mencuci tangan (hand wash).

Berdasarkan hasil pengabdian masyarakat kepada anak usia Sekolah Dasar di lingkungan sekitar SD 9/IV Kota Jambi terlihat anak cukup mengerti tentang materi pencegahan diare yang dibantu dijelaskan oleh ibu anak. Ibu-ibu juga terlihat bahwa diare menyetujui (mengangguk) bahwa diare harus dicegah agar anak Usia Sekolah Dasar tidak mengalami diare atau masuk rumah sakit. Ketika demonstrasi cara cuci tangan terlihat anak usia sekolah dasar bisa mengulang kembali cara mencuci tangan benar yang diajarkan oleh penyuluh.

Perilaku kesehatan akan akan lebih langgeng jika dibekali dengan pemahaman atau pengetahuan dari individu (Notoatmodjo, 2010). Perilaku kesehatan berupa pencegahan diare oleh ibu-ibu jika pengetahuan dan sikap telah terpatri dalam diri sehingga termitivasi untuk mencegah anak balita dari penyakit infeksi seperti diare.

Berdasarkan hasil penelitian yang dilakukan oleh Nurbaya, Armina dan Rino (2019) menunjukkan bahwa pengetahuan ada hububungan signifikan dengan pencegahan diare berulang ( $\mathrm{p}$ value 0,011 ) Nilai Odds Ratio berdasarkan hasil penelitian tersebut menunjukkkan sebanyak 3,289 kali pengetahuan yang kurang baik dapat mengakibatkan pencegahan diare berulang kurang baik.

Peningkatan pengetahuan paska penyuluhan kesehatan tergambarkan saat antusiasnya ibu anak SD bertanya tentang diare, mengevaluasi bersama-sama selama penyuluhan dan ketika ibu anak SD menjawab pertanyaan postes yang disediakan tim pengabmas. Ketika pretes, anak SD banyak yang menjawab dari 10 pertanyaan pretes tentang diare dengan skor terendah yaitu 4 dan skor tertinggi 8, sedangkan ketika postes pertanyaan terlihat skor terendah 7 dan skor tertinggi 10 dengan standar pengetahuan $70 \%$ bisa menjawab pertanyaan dari 10 soal.

Ketika sesi pretes, terlihat anak SD kurang mengetahui menjawab pertanyaan tentang faktor penyebab anak mengalami diare, tanda anak dehidrasi ringan sedang, cara mengatasi diare anak diare yaitu memperbanyak minum susu formula, cara mengatasi diare anak diare dengan memberi air rebusan daun jambu. Berdasarkan hasil postes menjawab pertanyaan tentang diare, terlihat anak SD bisa menjawab pertanyaan tentang penyebab diare, tanda anak diare dehidrasi ringan sedang, cara mengatasi diare pada anak serta mengetahui cara mencegah diare dari perilaku kesehatan. Setelah penyuluhan kesehatan, anak SD juga mampu mendemonstrasikan cara cuci tangan yang benar.

Berdasarkan

rekomendasi

Kemenkes (2011), pencegahan diare pada anak balita dapat diatasi jika ibu mengetahui faktor risiko penyebab diare. Faktor penyebab diare yang perlu dihindari yaitu berupa $5 \mathrm{~F}$. Penularan kuman melalui makanan (Food), tinja (feces), lalat (flies), peralatan makanan (fomites) dan jari tangan (finger). Oleh karena itu, tim penyuluh menekankan agar ibu-ibu mengupayakan mengindari risiko penularan kuman penyebab diare pada anak balita.

Berdasarkan panduan MTBS yang dikeluarkan oleh Kemenkes 2015 bahwa 
anak balita yang kena diare agar tercegah dari dehidrasi berupa anak mulai rewel atau masih mau minum, jika anak masih mau minum, menunjukkan anak belum mengalami dehidrasi berat, namun ketika anak sudah mulai rewel hingga sangat lemah dan anak malas minum hingga mata sangat cekung menunjukkan anak mulai terjadi dehidrasi sedang hingga berat. Hal ini juga penyuluh tekankan kepada ibu-ibu agar cermat memantau anak SD ketika mengalami diare agar tidak terjadi dehidrasi berat. Untuk ibu, ibu-ibu dan anak SD dianjurkan untuk cermat melakukan penanganan diare dan pencegahan diare berulang.

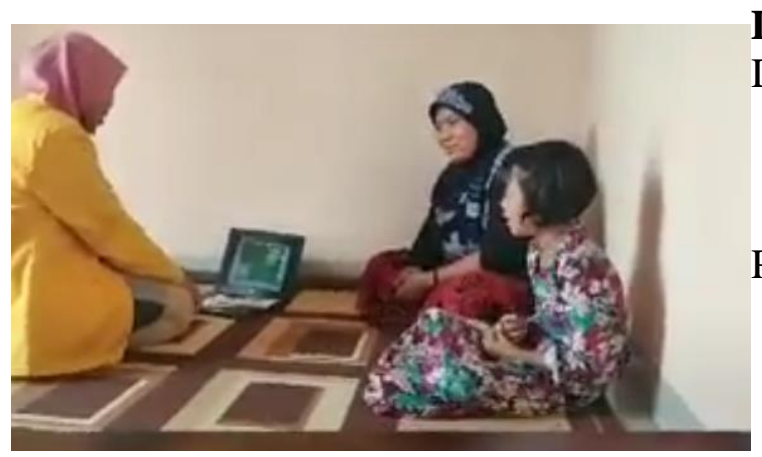

Gambar 1. Edukasi Pencegahan Diare

\section{KESIMPULAN DAN SARAN \\ 1. Kesimpulan}

Kegiatan pengabdian masyarakat berupa edukasi melalui pendidikan kesehatan dan demosntrasi hand wash terkait penyakit pencegahan diare pada anak usia sekolah dasar telah berjalan lancar walau harus datang ke rumah anak dengan protkol kesehatan dan walaupun kegiatan tertunda karena pandemi covid19 yang belum mengizinkan keluar rumah dan setelah peserta pendidikan kesehatan dan demonstrasi hand wash, anak SD memahami materi yang disampaikan oleh tim pengabdian masyarakat.

\section{Saran}

Melalui kegiatan pengabdian masyarakat ke rumah - rumah ini berupa kegiatan pendidikan kesehatan tentang pencegahan diare terhadap anak usia SD diharapkan dapat menambah pengetahuan dan pemahaman, serta mau menerapkan pencegahan diare dengan selalu cuci tangan benar setiap sebelum makan atau ketika jajan di SD.

\section{UCAPAN TERIMAKASIH}

Ucapan terimakasih kami sampaikan kepada STIKes Baiturrahim Jambi yang mendanani kegiatan pengabdian masyarakat ini, Ketua PPPM yang memebri fasilitasi kegiatan pengabdian masyarakat, kepada SD 9/IV Kota Jambi, dan mahasiswa yang .berpartisipasi dalam pengabdian ini.

\section{DAFTAR PUSTAKA}

Dinas Kesehatan Kota Jambi. 2018. Data Kasus Diare pada anak balita di Puskesmas Kota Jambi Tahun 2017 dan 2018

Puskesmas Putri Ayu. 2018. Laporan Kinerja Puskesmas Putri Ayu Tahun 2018 dan rencana Usulan Kegiaan tahun 2019. Dinas Kesehatan Kota Jambi

Riskesdes. 2018. Riset Kesehatan Dasar; RISKESDAS. Jakarta: Balitbang Kemenkes RI

Notoatmodjo, S. 2010. Promosi kesehatan dan ilmu perilaku. Jakarta: Rineka Cipta

Nurbaya, S., Armina, \& Rino. 2019. Hubungan Pengetahuan dan Sikap Ibu dengan Pencegahan Diare Berulang pada balita Di Kelurahan Tanjung Pinang Wilayah Kerja Puskesmas Tanjung Pinang Kota Jambi Tahun 2019. Skripsi.

Kemenkes. 2011. Panduan sosialisasi tatalaksana diare balita untuk petugas kesehatan. 